\title{
Financial Performance Evaluation of Turkish Energy Companies with Fuzzy AHP and Fuzzy TOPSIS Methods
}

\author{
Kemal Eyüboğlu ${ }^{\mathrm{a}} \quad$ Pelin Çelik
}

\begin{abstract}
Turkey's economy has expanded in recent years with the increase in energy consumption. Energy is a key input in production and plays a crucial role in the development of an economy. Energy sector interacts with other sectors hence the performances of energy firms are inevitable to follow-up. In the study thirteen energy firms are evaluated with 5 main and 15 sub-criteria for the period of 2008-2013. The 15 sub-criteria are classified in the following main criteria: liquidity, activity, financial leverage, profitability and growth ratios. The weights of the ratios are determined by Fuzzy AHP and then Fuzzy TOPSIS method is used for the rankings of the energy firms. Traditional multi-criteria decision making methods are not used in this study, due to the fact that they are insufficient under uncertainty. After 2008 global financial crisis, the uncertainty has increased all over the world hence the usage of fuzzy methods can provide better results under these conditions. Findings show that Avrasya Oil, Turcas and Aksu have the highest ranking.
\end{abstract}

Keywords: Performance Evaluation, Fuzzy AHP, Fuzzy TOPSIS, Energy Sector, Multi-Criteria Decision Making

JEL Classification: L61, G11, Q40

\section{Introduction}

Energy is one of the most important parts of economic and social development. In addition, it is indispensable and non-substitutable in numerous fields of daily life. The importance of energy is increasing day by day in consequence of rapid development in technology, population growth and increase in life standards in the public life. Net growth of the consumption of energy is actualized by developing economies. Turkey has an increasing population with its developing economy. It performs transformation from agriculture to industry in contrast to developed economies and it also takes part in the most rapid developing energy markets. While the global energy needs which increases with the amount of $\% 2$ in a year, it is at \%6-\%8 level that 3-4 times more than world average energy need in Turkey (dogaka.gov.tr). From this point, in developing economies like Turkey, energy sectors have important structural links with other sectors of economy. Following the developments of these sectors which provide substantially input to other sector of economy is quite important. Profitability which is one of the main purposes of firms has more importance in competitive business environment. It is the fact that the high performing firms will exist in this competition environment. The performance of these firms will be important not only for their subsistence but also for investors, creditors and economy of the country.

${ }^{a}$ PhD., Karadeniz Technical University, The Faculty of Economic and Administrative Sciences Department of Business Administration, Trabzon, Turkiye, keyuboglu@ktu.edu.tr

${ }^{b}$ Res. Assist., Karadeniz Technical University, The Faculty of Economic and Administrative Sciences, Department of Business Administration, Trabzon, Turkiye, pcelik@ktu.edu.tr 
In this sense, it is inevitable to evaluate the performances of the energy firms. Financial ratios are widely used for evaluating a firm's performance and financial situation. The performance evaluation of a firm helps investors to make investment decisions as well as gives information about the firms. In the literature, researchers have used various multi-criteria decision making models (MCDM) for the performance evaluation in different sectors. For instance, Feng and Wang (2000); Wang (2008) carried out TOPSIS and Fuzzy TOPSIS methods for the performance evaluation in aviation, Yurdakul and iç (2003) used TOPSIS method in automotive sectors respectively. Chou and Liang (2001) used AHP in shipping, Xia and Wu (2007); Chamodrakas and Martakos (2010) utilized AHP and Fuzzy AHP for supplier selection respectively. Also Yalçın, Bayraktaroğlu and Kahraman (2012) used Fuzzy AHP, VIKOR and TOPSIS methods in manufacturing sector. Fuzzy AHP and TOPSIS are carried out in performance evaluation of airports (Chang, Cheng \& Wang, 2003); cement firms (Ertuğrul \& Karakasoğlu, 2009) and banks (Mandic, Delibasic, Knezevic \& Benkovic, 2014; Mahrooz, Maedeh \& Morteza, 2013; Seçme, Bayraktaroğlu \& Kahraman, 2009). Fuzzy AHP (Weifeng \& Huihuan, 2008) and Fuzzy TOPSIS methods are also used in banking (Akkoç \& Vatansever, 2013). Sun (2010) also utilized Fuzzy AHP and Fuzzy TOPSIS methods for computer companies. Kalogeras, Baourakis, Zopounidis and Van Dijk (2005) employed PROMETHEE for food firms. Ignatius, Behzadian, Malekan and Lalitha (2012) used PROMETHEE II for the performance evaluation of the automotive firms. Erginel and Sentürk (2011) carried out Fuzzy ANP for the ranking of GSM operators. For the energy firms Ergül (2010) and Sakarya, Yıldırım and Akkuş (2015) used TOPSIS method.

As it is seen there are few studies in the literature that Fuzzy AHP and Fuzzy TOPSIS methods are integrated for the performance evaluation of energy firms. In the study, we evaluate the financial performances of energy firms for the period of 2008-2013 with utilizing the Fuzzy AHP and Fuzzy TOPSIS methods. The weights of the criteria are determined by Fuzzy AHP method and then Fuzzy TOPSIS method is used for the rankings of the energy firms. Traditional multi-criteria decision making methods are not used in this study, due to the fact that they are insufficient under uncertainty. After 2008 global crisis, the uncertainty has increased all over the world hence the usage of fuzzy methods can provide better results under these conditions. This study will contribute to literature in terms of present the general outlook of Turkish energy sector after the 2008 global crisis and will give chance to investors and creditors to evaluate the performance of firms.

In this study, we use the financial data of 13 energy firms traded in Borsa Istanbul. The dataset consists of 15 sub-criteria which are classified in the following main criteria: liquidity, activity, financial leverage, profitability and growth ratios. The rest of the paper is organized as follows. Section 2 explains the fuzzy sets, Fuzzy AHP and Fuzzy TOPSIS methods which are used in the study. Section 3 describes the data presents the empirical findings and Section 4 concludes and suggests for the future studies.

\section{Fuzzy Sets}

The classical set theory is built on the concept of "set" of which a variable is either a member or not (Chen \& Pham, 2000: 1). In classical logic, variables are defined as true or false, black or white, 0 or 1 (Kartalopoulos, 1995: 5). Thus the real world applications are complex and it is hard to describe with crisp numbers.

Fuzzy set theory was investigated in the 1920's and 1930's by Lukasiewicz and Tarski (Pelletier, 2000: 343), but it is first introduced by Zadeh in 1965 to deal with the uncertainty due to imprecision and vagueness (Tanaka, 1997: 1; Chen, Yizeng, Jian \& Yuanyuan, 2016: 16). Fuzzy set theory is an important tool to reinforce the comprehensiveness and moderateness of the decision making process (Seçme et al., 2009: 11701). Fuzzy set is a special class of objects which is defined by a membership function (Kumar, Shankar \& Debnath, 2015: 449). A tilde ' $~$ ' is used above a letter in the function when it presents fuzzy set. In the literature the most widely used fuzzy numbers are triangular and trapezoidal numbers. In this study triangular fuzzy numbers (TFNs) are used to consider the fuzziness of measurements and evaluations. A TFN, $\tilde{M}$ on $\mathrm{R}$ is provided by its membership function $\mu_{\tilde{M}}(x): U \subseteq R \rightarrow[0,1]$ which is linear piecewise continuous as (Kamvysi, Gotzamani, Andronikidis \& Georgiou, 2014: 1087): 


$$
\mu_{\tilde{M}}(x)= \begin{cases}\frac{x}{m-l}-\frac{l}{m-l} & , x \in[l, m] \\ \frac{u}{u-m}-\frac{x}{u-m} & , x \in[m, u] \\ 0 & , \text { otherwise }\end{cases}
$$

If $M_{1}=\left(I_{1}, m_{1}, u_{1}\right)$ and $M_{2}=\left(I_{2}, m_{2}, u_{2}\right)$ and then the operational laws of addition, multiplication, reciprocal and division for these two TFN can be presented as follows:

$$
\begin{aligned}
& M_{1} \oplus M_{2}=\left(I_{1}, m_{1}, u_{1}\right) \oplus\left(I_{2}, m_{2}, u_{2}\right)=\left(I_{1}+I_{2}, m_{1}+m_{2}, u_{1}+u_{2}\right) \\
& M_{1} \otimes M_{2}=\left(I_{1}, m_{1}, u_{1}\right) \otimes\left(I_{2}, m_{2}, u_{2}\right) \approx\left(I_{1} \times I_{2}, m_{1} \times m_{2}, u_{1} \times u_{2}\right) \\
& M_{1}^{-1}=\left(I_{1}, m_{1}, u_{1}\right)^{-1}=\left(1 / u_{1}, 1 / m_{1}, 1 / I_{1}\right) \\
& M_{1}(/) M_{2} \approx\left(I_{1} / u_{2}, m_{1} / m_{2}, u_{1} / I_{2}\right)
\end{aligned}
$$

The linguistic variables and fuzzy ratings for the criteria are shown in Table 1.

Table 1. Linguistic Terms For Criteria Ratings

\begin{tabular}{ccccc}
\hline Linguistic terms & $\begin{array}{c}\text { Fuzzy } \\
\text { numbers }\end{array}$ & Membership function & Domain & $\begin{array}{c}\text { Triangular Fuzzy } \\
\text { Scale }\end{array}$ \\
\hline Just Equal & & & & $(1,1,1)$ \\
Equal Importance & $\tilde{1}$ & $\mu_{M}(x)=(3-x) /(3-1)$ & $1 \leq x \leq 3$ & $(1,1,3)$ \\
Weak Importance & $\tilde{3}$ & $\mu_{M}(x)=(x-1) /(3-1)$ & $1 \leq x \leq 3$ & $(1,3,5)$ \\
& & $\mu_{M}(x)=(5-x) /(5-3)$ & $3 \leq x \leq 5$ & \\
Strong Importance & $\tilde{5}$ & $\mu_{M}(x)=(x-3) /(5-3)$ & $3 \leq x \leq 5$ & $(3,5,7)$ \\
Very Strong Importance & $\tilde{7}$ & $\mu_{M}(x)=(7-x) /(7-5)$ & $5 \leq x \leq 7$ & \\
Extremely Preferred & & $\mu_{M}(x)=(x-5) /(7-5)$ & $5 \leq x \leq 7$ & $(5,7,9)$ \\
& $\tilde{9}$ & $\mu_{M}(x)=(9-x) /(9-7)$ & $7 \leq x \leq 9$ & \\
\hline
\end{tabular}

\subsection{Fuzzy AHP Method}

Analytical Hierarchy Process (AHP) is an approach that was developed by Saaty (1990) which involves structured multi-criteria into a hierarchy, assessing the importance of these criteria, comparing the alternatives for each criterion and determining the ranking of the alternatives (Hu \& Peng, 2008: 1095). AHP is a mathematical decision making technique that takes into consideration of both qualitative and quantitative ways of decisions and it increases the basic decisions by the aspect of reducing complex decisions (Punniyamoorty, Ponnusamy \& Lakshmi, 2012: 81). AHP is a useful method utilizing subjective determinations for solving complex decision making problems (Lin, 2010: 881).

In general, incomplete and uncertain data information could be introduced to decision making problems. Also the decisions made by the experts depend on subjective thoughts; therefore it is more suitable to use fuzzy numbers instead of crisp numbers (Gu \& Zhu, 2006: 401). The fuzzy AHP method 
reflects decision maker's appraisal of fuzziness and vagueness when making pairwise comparisons of criteria and alternatives (Lee et al., 2010: 2238). In literature, Fuzzy AHP is regularly used in supplier selection problems (Bronja \& Bronja, 2015; Sultana, Ahmed \& Azeem, 2015; Rezaei, 2014; Kılınçcı \& Önal, 2011; Chamodrakas \& Martakos, 2010; Xia \& Wu, 2007). Fuzzy AHP is also used in different fields by following researchers: Beşkese, Demir, Özcan and Ökten (2015) in the landfill site selection; Nguyen et al. (2015) in the selection of machine tools; Belgin (2015) in optimization of multi objective simulation system. In addition Mangla, Kumar and Mukesh (2015) evaluated risk analysis in green supply chain; Chen, Hsieh and Do (2015) examined teaching performance; Kumar (2015) analyzed customer preferences; Isaai, Kanani, Tootoonchi and Afzali (2011) examined intelligent timetable with Fuzzy AHP method.

In this study, we use Chang (1996)'s extended analysis to evaluate the weights of the criteria. Chang's extended analysis consists of the following steps (Chang, 1996: 649; Büyüközkan, Kahraman \& Ruan, 2004: 262; Mosadeghi, Warnken, Tomlinsen \& Mirfenderesk, 2015: 58):

Step 1: Let $X=\left\{x_{1}, x_{2}, \ldots, x_{n}\right\}$ be an object set and $U=\left\{u_{1}, u_{2}, \ldots, u_{m}\right\}$ be a goal set. Accourding to extent analysis, the method can be performed with respect to each object for each goal resulting in $\mathrm{m}$ extent analysis values for each object, given as $M_{g i}^{1}, M_{g i}^{2}, \ldots, M_{g i}^{m}, i=1,2, \ldots, n$, where all $M_{g i}^{j}(j=1,2, \ldots$, $m$ ) are triangular fuzzy numbers representing the performance of the object with regard to each goal $u_{j}$. The values of fuzzy extensions for $i$-th object are given in Equation (3);

$S_{i}=\sum_{j=1}^{m} M_{g i}^{j} \otimes\left[\sum_{i=1}^{n} \sum_{j=1}^{m} M_{g i}^{j}\right]^{-1}$

In order to obtain the equation $\left[\sum_{i=1}^{n} \sum_{j=1}^{m} M_{g i}^{j}\right]^{-1}$, it is necessary to perform additional fuzzy operations with $m$ values of the extended analysis, which is represented in Equation (4) and (5);

$$
\begin{aligned}
& \sum_{j=1}^{m} M_{g i}^{j}=\left(\sum_{j=1}^{m} l_{j}, \sum_{j=1}^{m} m_{j}, \sum_{j=1}^{m} u_{j}\right) \\
& {\left[\sum_{i=1}^{n} \sum_{j=1}^{m} M_{g i}^{j}\right]=\left(\sum_{i=1}^{n} l_{i}, \sum_{i=1}^{n} m_{i}, \sum_{i=1}^{n} u_{i}\right)}
\end{aligned}
$$

It is necessary to calculate the inverse vector using Equation (6);

$$
\left[\sum_{i=1}^{n} \sum_{j=1}^{m} M_{g i}^{j}\right]^{-1}=\left(\frac{1}{\sum_{i=1}^{n} u_{i}}, \frac{1}{\sum_{i=1}^{n} m_{i}}, \frac{1}{\sum_{i=1}^{n} l_{i}}\right)
$$

Step 2: The degree of possibility for $M_{2}$ is defined as:

$$
V\left(M_{2} \geq M_{1}\right)=\sup _{y \geq x}\left[\min \left(\mu_{M_{1}}(x), \mu_{M_{2}}(y)\right)\right]
$$

It can be represented in the following manner by Equation (7);

$$
V\left(M_{2} \geq M_{1}\right)=h g t\left(M_{2} \cap M_{1}\right) \mu_{M 2}(d)
$$




$$
=\left\{\begin{array}{cc}
1, \quad \text { if } & m_{2} \geq m_{1} \\
0, \quad \text { if } & l_{1} \geq u_{2} \\
\frac{l_{1}-u_{2}}{\left(m_{2}-u_{2}\right)-\left(m_{1}-l_{1}\right)}, & \text { otherwise }
\end{array}\right.
$$

where $d$ is the ordinate of the highest intersection point between $\mu M_{1}$ and $\mu M_{2}$. We need both the values of $V\left(M_{2} \geq M_{1}\right)$ and $V\left(M_{1} \geq M_{2}\right)$ to compare $\mu M_{1}$ and $\mu M_{2}$.

Step 3: The degree of possibility of fuzzy number $M_{i}(i=1,2, \ldots, \mathrm{k})$ can be defined by Equation (10);

$$
\begin{aligned}
& \mathrm{V}\left(\mathrm{M} \geq \mathrm{M}_{1}, \mathrm{M}_{2}, \ldots, \mathrm{M}_{\mathrm{k}}\right) \\
& =\mathrm{V}\left[\left(\mathrm{M} \geq \mathrm{M}_{1}\right) \text { and }\left(\mathrm{M} \geq \mathrm{M}_{2}\right) \mathrm{i} \ldots \mathrm{i}\left(\mathrm{M} \geq \mathrm{M}_{\mathrm{k}}\right)\right] \\
& =\min V\left(M \geq M_{i}\right), i=1,2,3
\end{aligned}
$$

Let assume that Equation (11);

$$
\mathrm{d}^{\prime}(\mathrm{Ai})=\min V\left(S_{i} \geq S_{k}\right)
$$

for $k=1,2, \ldots, \mathrm{n} ; k \neq i$. The weight vector is obtained by Equation (12);

$W^{\prime}=\left(d^{\prime}\left(A_{1}\right), d^{\prime}\left(A_{2}\right), \ldots, d^{\prime}\left(A_{n}\right)\right)^{\top}$

where, $A_{i}(i=1,2, \ldots, n)$ consists of $n$ elements.

Step 4: Through normalization, the weight vectors are reduced to Equation (13);

$W=\left(d\left(A_{1}\right), d\left(A_{2}\right), \ldots, d\left(A_{n}\right)\right)^{\top}$

where $W$ represents a non-fuzzy number.

\subsection{Fuzzy TOPSIS Method}

TOPSIS, which is developed by Hwang and Yoon (1981), is a multi-attribute decision making method to identify solutions from a finite set of alternatives (Li, 2009: 220). In the classical TOPSIS method, the ratings of alternatives are presented by real values. However it is difficult to determine the values of ratings of the alternatives with respect to local criteria, these ratings are presented by fuzzy values (Dymova, Sevastjanov \& Tikhonenko, 2015: 117). In TOPSIS, it is important to define positive ideal solution (PIS) and negative ideal solution (NIS). The ideal solution composed of best attribute values, whereas the negative ideal solution is comprised of all worst attribute values (Yue, 2013: 112). The alternatives are compared with these PIS and NIS, to find out the distance (Viswanadham \& Samvedi, 2013: 6490). The PIS is the solution that maximizes the benefit criteria and minimizes the cost criteria; whereas the NIS maximizes the cost criteria and minimizes the benefit criteria (Lee, Chiang \& Chen, 2012: 40). The best alternative should have the shortest distance from the PIS and the farthest distance from NIS.

In TOPSIS method the ratings of alternatives are crisp values, however due to vagueness of the decision data, crisp data are ineligible to model real life decision problems (Lee et al., 2012: 41). In this paper, we adopt the extension of TOPSIS method introduced by Chen (2000), to achieve the ranking of the 
alternatives in fuzzy environment. The fuzzy TOPSIS calculation steps are given as follows (Song, Ming, Wu \& Zhu, 2013: 1176; Viswanadham \& Samvedi, 2013: 6491):

Step 1: Creating the Decision Matrix: Firstly aggregated ratings are calculated using Equation (14):

$$
\tilde{X}_{i j}=\frac{1}{s}\left[\tilde{x}_{i j}^{1} \oplus \tilde{x}_{i j}^{2} \oplus \ldots \tilde{x}_{i j}^{s}\right]
$$

where $\tilde{x}_{i j}^{s}$ is the performance rating value obtained from s-th decision maker. The fuzzy decision matrix is created using Equation (15):

$\boldsymbol{D}=\left[\begin{array}{ccccc}\widetilde{x}_{11} & \cdots & \widetilde{x}_{1 j} & \cdots & \widetilde{x}_{1 n} \\ \vdots & & \vdots & \vdots \\ \widetilde{x}_{i 1} & \cdots & \widetilde{x}_{i j} & \cdots & \widetilde{x}_{i n} \\ \vdots & & \vdots & \vdots \\ \widetilde{x}_{m 1} & \cdots & \widetilde{x}_{m j} & \cdots & \widetilde{x}_{m n}\end{array}\right]$ where $\tilde{x}_{i j}=\left(a_{i j}, b_{i j}, c_{i j}\right)$

Step 2: Normalizing the Decision Matrix: The normalized fuzzy matrix is shown by $\widetilde{R}=\left[\tilde{r}_{i j}\right]_{m x n}$. B represents benefit criteria and $\mathrm{C}$ represents cost criteria.

$$
\begin{aligned}
& r_{i j}=\left(\frac{a_{i j}}{c_{j}^{*}}, \frac{b_{i j}}{c_{j}^{*}}, \frac{c_{i j}}{c_{j}^{*}}\right), j \in B \\
& r_{i j}=\left(\frac{a_{j}^{-}}{c_{i j}}, \frac{a_{j}^{-}}{b_{i j}}, \frac{a_{j}^{-}}{a_{i j}}\right), j \in C \\
& c_{j}^{*}=\max _{i} c_{i j}, \quad \text { if } j \in B \\
& a_{j}^{-}=\min _{i} a_{i j}, \text { if } j \in C
\end{aligned}
$$

After normalization, the fuzzy elements take the values between $[0,1]$.

Step 3: Calculating the Weighted Normalized Fuzzy Decision Matrix: The weighted normalized decision matrix is shown as $\tilde{V}=\left[\tilde{v}_{i j}\right]_{m x n}$;

$\tilde{v}_{i j}=\tilde{r}_{i j} \otimes w_{j}, \quad i=1,2, \ldots, m$, and $j=1,2, \ldots, n$

Step 4: Calculating the Positive and Negative Ideal Solutions: Fuzzy Positive Ideal Solution (FPIS) and Fuzzy Negative Ideal Solution (FNIS) can be given as:

$$
\begin{aligned}
& A^{*}=\left(\tilde{v}_{1}^{*}, \tilde{v}_{2}^{*}, \ldots, \tilde{v}_{n}^{*}\right) \\
& A^{-}=\left(\tilde{v}_{1}^{-}, \tilde{v}_{2}^{-}, \ldots, \tilde{v}_{n}^{-}\right)
\end{aligned}
$$

where $v_{j}^{*}=(1,1,1), v_{j}^{-}=(0,0,0)$ and $j=1,2, \ldots, n$

Step 5: Calculating the Distances from FPIS and FNIS: By Equations (19) and (20), the distances from FPIS and FNIS are calculated.

$$
d_{i}^{*}=\sum_{j=1}^{n} d\left(\tilde{v}_{i j}, \tilde{v}_{j}^{*}\right), i=1,2, \ldots, m
$$


$d_{i}^{-}=\sum_{j=1}^{n} d\left(\tilde{v}_{i j}, \tilde{v}_{j}^{-}\right), i=1,2, \ldots, m$

The distance between two triangular fuzzy numbers $\tilde{a}=\left(a_{1}, a_{2}, a_{3}\right)$ and $\tilde{b}=\left(b_{1}, b_{2}, b_{3}\right)$ is calculated by Equation (21):

$d(\widetilde{a}, \tilde{b})=\sqrt{\frac{1}{3}\left[\left(a_{1}-b_{1}\right)^{2}+\left(a_{2}-b_{2}\right)^{2}+\left(a_{3}-b_{3}\right)^{2}\right]}$

Step 6: Computing the Closeness Coefficients: Closeness coefficients of each alternative are computed by Equation (22):

$C C_{i}=\frac{d_{i}^{-}}{d_{i}^{*}+d_{i}^{-}}, i=1,2, \ldots, m$

If $C C_{i}$ value of the alternative is close to 1 , then the alternative is closer to FPIS and farther from the FNIS.

\section{Data and Findings}

The purpose of the study is to evaluate the financial performances of Turkish energy firms during the period 2008-2013. All the financial ratios are calculated with the help of financial statements of the firms. The sample consists of thirteen energy firms. These are Akenerji (AKENR), Aksa (AKSEN), Aksu (AKSUE), Anel Electric (ANELE), Avrasya Oil (AVTUR), Ayen Energy (AYEN), Aygaz (AYGAZ), Emek Electric (EMKEL), Gersan Electric (GEREL), Ipek Dogal Energy (IPEKE), Petkim (PETKM), Turcas (TRCAS), Tupras (TUPRS) and Zorlu Energy (ZOREN). The financial performance of energy firms are evaluated with 5 main and 15 sub-criteria. These performance criteria are indicated in Table 2.

Table 2. Used Performance Criteria

\begin{tabular}{|c|c|c|c|}
\hline Main Criteria & Code & $\begin{array}{l}\text { Formula } \\
\text { Sub-Criteria }\end{array}$ & Ratio \\
\hline \multirow{3}{*}{ Growth Ratios } & \multirow{3}{*}{ (GR) } & $\left.\left[\left(S_{t}-S_{t-1}\right) / S_{t-1}\right)\right]^{*} 100^{1}$ & Sales Growth \\
\hline & & $\left.\left[\left(A_{t}-A_{t-1}\right) / A_{t-1}\right)\right]^{*} 100^{2}$ & Assets Growth \\
\hline & & $\left.\left[\left(E_{t}-E_{t-1}\right) / E_{t-1}\right)\right]^{*} 100^{3}$ & Shareholders' Equity Growth \\
\hline \multirow{4}{*}{ Activity Ratios } & \multirow{4}{*}{$(A R)$} & Total Net Sales/Accounts Receivables & Accounts Receivable Turnover \\
\hline & & Sales/Fixed Assets & Fixed Assets Turnover \\
\hline & & Sales/Total Equity & Equity Turnover \\
\hline & & Sales/Total Assets & Total Assets Turnover \\
\hline \multirow{2}{*}{$\begin{array}{l}\text { Financial } \\
\text { Leverage Ratios }\end{array}$} & \multirow{2}{*}{ (FLR) } & Total Debt/Total Assets & Debt Ratio \\
\hline & & Total Debt/ Total Equity & Debt To Equity Ratio \\
\hline \multirow{3}{*}{$\begin{array}{l}\text { Profitability } \\
\text { Ratios }\end{array}$} & \multirow{3}{*}{$(P R)$} & Net income(loss)/Total Assets & Return On Assets (ROA) \\
\hline & & Net income(loss)/Total Equity & Return On Equity (ROE) \\
\hline & & Net income(loss)/ Sales & Net Profit Margin \\
\hline \multirow{3}{*}{ Liquidity Ratios } & \multirow{3}{*}{ (LR) } & Current Assets/Current Liabilities & Current Ratio \\
\hline & & Quick Assets/Current Liabilities & Quick Ratio \\
\hline & & Cash and Cash Equivalent Assets/Current & Cash Ratio \\
\hline
\end{tabular}

The weights of the criteria are determined by using Fuzzy AHP. Four decision makers from different areas (creditor, shareholder, academic and a sector employee) are selected to represent the different expectations of stakeholders to evaluate the importance of financial ratios with the help of pairwise comparisons. Fuzzy AHP is proposed to take the decision makers subjective judgments into consideration and to reduce the uncertainty and vagueness in the decision process (Ertuğrul \& Karakaşoglu, 2009: 706). 
The weights of the criteria are first determined by using Fuzzy AHP. The pairwise comparison scores were examined by four decision makers. Thus decision makers' pair-wise comparison scores are transformed into triangular fuzzy numbers as in Table 3.

Table 3. Fuzzy Pairwise Comparison Matrix

\begin{tabular}{cccccc}
\hline & GR & AR & FLR & PR & LR \\
\hline GR & $(1,1,1)$ & $(1,1,3)$ & $(1,1,3)$ & $(0.143,0.2,0.333)$ & $(0.2,0.333,1)$ \\
AR & $(0.333,1,1)$ & $(1,1,1)$ & $(1,1,3)$ & $(0.2,0.333,1)$ & $(0.2,0.333,1)$ \\
FLR & $(0.333,1,1)$ & $(0.143,0.2,0.333)$ & $(1,1,1)$ & $(0.2,0.333,1)$ & $(0.2,0.333,1)$ \\
PR & $(3,5,7)$ & $(1,3,5)$ & $(1,3,5)$ & $(1,1,1)$ & $(1,3,5)$ \\
LR & $(1,3,5)$ & $(1,3,5)$ & $(1,3,5)$ & $(0.2,0.333,1)$ & $(1,1,1)$ \\
\hline
\end{tabular}

After creating fuzzy pairwise comparison matrix, weights of all criteria and sub-criteria are assessed by the help of Fuzzy AHP. According to the Fuzzy AHP method, firstly synthetic values must be calculated. The synthetic values for each criterion are calculated by Equation (3);
$S 1=(3.343,3.533,4.333)$
$\otimes(0.017,0.028,0.052)=(0.056,0.1,0.435)$
$S 2=(2.733,3.667,7)$
$\otimes(0.018,0.028,0.050)=(0.046,0.104,0.365)$
$S 3=(1.876,2.867,4.333)$
$\otimes(0.018,0.028,0.050)=(0.031,0.081,0.226)$
$S 4=(7,15,23)$
$\otimes(0.018,0.028,0.050)=(0.117,0.424,1.201)$
$S 5=(4 \cdot 2,10 \cdot 333,17)$
$\otimes(0.018,0.028,0.050)=(0.07,0.292,0.888)$

The synthetic values are compared by using Equation (8) and (9);

$$
\begin{array}{ll}
V(S 1 \geq S 2)=1, V(S 1 \geq S 4)=0.495 & V(S 1 \geq S 3)=1, V(S 1 \geq S 5)=1 \\
V(S 2 \geq S 1)=1, V(S 2 \geq S 4)=0.437 & V(S 2 \geq S 3)=1 \quad V(S 2 \geq S 5)=1 \\
V(S 3 \geq S 1)=1, V(S 3 \geq S 4)=0.443 & V(S 3 \geq S 2)=1, V(S 3 \geq S 5)=1 \\
V(S 4 \geq S 1)=1, V(S 4 \geq S 3)=1 & V(S 4 \geq S 2)=1, V(S 4 \geq S 5)=1 \\
V(S 5 \geq S 1)=1, V(S 5 \geq S 3)=1 & V(S 5 \geq S 2)=1, V(S 5 \geq S 4)=1
\end{array}
$$

Then the priority weights are calculated by using Equation (11);

$$
\begin{aligned}
& d^{\prime}\left(S_{1}\right)=\min (1,1,0.495,1)=0.495 \\
& d^{\prime}\left(S_{2}\right)=\min (1,1,0.437,1)=0.437 \\
& d^{\prime}\left(S_{3}\right)=\min (1,1,0.443,1)=0.443 \\
& d^{\prime}\left(S_{4}\right)=\min (1,1,1,1)=1 \\
& d^{\prime}\left(S_{5}\right)=\min (1,1,1,1)=1
\end{aligned}
$$

Priority weights form $W^{\prime}=(0.495,0.437,0.443,1,1)^{\top}$ vector. After the normalization, the weight vector for the main criteria is calculated as $(0.1467,0.1294,0.1314,0.2963,0.2963)$. Then, weights of subcriteria are calculated similarly ${ }^{4}$. After formulations the weights of the financial ratios are reported in Table 4. 
Table 4. Weights of Main and Sub-Criteria

\begin{tabular}{|c|c|c|c|}
\hline Main Criteria & Weights & Sub-Criteria & Weights \\
\hline \multirow{3}{*}{ Growth Ratios } & \multirow{3}{*}{0.1467} & Sales Growth & 0.071 \\
\hline & & Assets Growth & 0.071 \\
\hline & & Shareholders' Equity Growth & 0.004 \\
\hline \multirow{4}{*}{ Activity Ratios } & \multirow{4}{*}{0.1294} & Accounts Receivable Turnover & 0.051 \\
\hline & & Equity Turnover & 0.051 \\
\hline & & Fixed Assets Turnover & 0.015 \\
\hline & & Total Assets Turnover & 0.012 \\
\hline \multirow{2}{*}{ Leverage Ratios } & \multirow{2}{*}{0.1314} & Debt Ratio & 0.066 \\
\hline & & Debt To Equity Ratio & 0.066 \\
\hline \multirow{3}{*}{ Profitability Ratios } & \multirow{3}{*}{0.2963} & Return On Equity (ROE) & 0.099 \\
\hline & & Return On Assets (ROA) & 0.099 \\
\hline & & Net Profit Margin & 0.099 \\
\hline \multirow{3}{*}{ Liquidity Ratios } & \multirow{3}{*}{0.2963} & Current Ratio & 0.142 \\
\hline & & Quick Ratio & 0.142 \\
\hline & & Cash Ratio & 0.013 \\
\hline
\end{tabular}

As can be seen from the Table 4 it can be concluded that in the process of financial performance evaluation of the Turkish energy firms, the main criteria of liquidity and profitability ratios are the most important with same weights $(0.2963)$, followed by the criteria of growth ratio $(0.1467)$, financial leverage ratio $(0.1314)$ and the activity ratio $(0.1294)$ respectively. In addition it is determined that the most important sub-criteria are current and quick ratios (0.142) followed by ROA, ROE and net profit margin ratios (0.099).

Then Fuzzy TOPSIS method is used for the ranking of thirteen energy firms according to the relative distance values of alternatives $\left(\mathrm{CC}_{\mathrm{i}}\right)$. Since one representative indicator of a company has six values from 2008 to 2013, the values of indicators are set into triangular fuzzy numbers and setting formula is presented as follows.

Let $b_{\mathrm{ij}}(\mathrm{e})$ indicate the value of indicator $j$ for company $i$ on the period $e$, where $i=1,2, \ldots, 13 ; j=$ $1,2, \ldots, 15 ; e=2008,2009, \ldots, 2013$.

To reach the values of the six periods, the representative indicator of company $i$ on indicator $j$ presented with the triangular fuzzy number $\left(g_{i j}^{l}, g_{i j}^{m}, g_{i j}^{r}\right)$ is defined as:

$g_{i j}^{l}=\min \left\{b_{i j} \mid e=2008,2009, \ldots, 2013\right\}$,

$g_{i j}^{m}=\frac{1}{6} \sum_{e=2008}^{2013} b_{i j}(e)$

and,

$$
g_{i j}^{r}=\max \left\{b_{i j}(e) \mid e=2008,2009, \ldots, 2013\right\}
$$

Utilizing the method of triangular fuzzy numbers, the fuzzy numbers of financial ratios are shown in Table 5. 
Financial Performance Evaluation of Turkish Energy Companies with Fuzzy AHP and Fuzzy TOPSIS Methods

Table 5. Triangular Fuzzy Numbers of Financial Ratios

\begin{tabular}{|c|c|c|c|c|c|}
\hline & Current Ratio & Quick Ratio & Cash Ratio & Acc. Rec. Turnover & Equity Turnover \\
\hline AKENR & $(0.34,1.01,2.14)$ & $(0.31,0.79,1.87)$ & $(0.09,0.43,0.91)$ & $(4.02,6.46,9.54)$ & $(-40.75,-4.78,18.66)$ \\
\hline AKSEN & $(0.83,1.13,1.48)$ & $(0.29,0.84,1.26)$ & $(0.02,0.07,0.12)$ & $(1.90,6.33,12.55)$ & $(1.11,1.57,1.87)$ \\
\hline AKSUE & $(0.20,23.68,70.59)$ & $(0.00,21.56,62.29)$ & $(0.00,19.41,59.30)$ & $(3.71,5654.58,33871)$ & $(1.05,9.58,16.78)$ \\
\hline ANELE & $(1.11,1.49,1.78)$ & $(0.29,0.84,1.26)$ & $(0.02,0.07,0.12)$ & $(1.28,3.48,5.62)$ & $(1.11,1.57,1.87)$ \\
\hline AVTUR & $(0.45,27.46,145.6)$ & $(0.16,16.25,85.89)$ & $(0.00,15.61,85.81)$ & $(1.81,334.0,917.0)$ & $(0.02,72.94,160.79)$ \\
\hline AYEN & $(0.36,0.98,1.66)$ & $(0.29,0.77,1.33)$ & $(0.01,0.23,0.47)$ & $(7.13,8.33,10.06)$ & $(0.44,0.72,1.68)$ \\
\hline AYGAZ & $(0.97,1.51,1.90)$ & $(0.82,1.02,1.34)$ & $(0.26,0.47,0.73)$ & $(11.25,15.90,18.40)$ & $(-5.76,8.37,22.43)$ \\
\hline EMKEL & $(0.52,0.77,0.95)$ & $(0.17,0.39,0.59)$ & $(0.00,0.04,0.10)$ & $(2.43,8.78,23.24)$ & $(1.01,2.94,8.60)$ \\
\hline GEREL & $(1.25,1.88,2.79)$ & $(0.60,1.07,2.04)$ & $(0.08,0.34,0.57)$ & $(3.72,5.87,8.36)$ & $(1.85,2.35,2.86)$ \\
\hline IPEKE & $(2.00,4.68,8.47)$ & $(1.23,3.91,7.40)$ & $(0.72,3.55,7.03)$ & $(18.23,28.57,47.55)$ & $(1.39,1.72,1.99)$ \\
\hline PETKM & $(1.39,1.55,1.76)$ & $(0.88,0.93,1.03)$ & $(0.11,0.23,0.31)$ & $(5.54,7.27,10.32)$ & $(1.40,2.04,2.61)$ \\
\hline TRCAS & $(2.13,7.57,12.32)$ & $(1.96,7.29,11.89)$ & $(1.24,5.90,11.20)$ & $(4.04,6.65,9.13)$ & $(0.020,0.07,0.11)$ \\
\hline \multirow[t]{2}{*}{ ZOREN } & $(0.35,0.50,0.64)$ & $(0.29,0.33,0.39)$ & $(0.01,0.09,0.17)$ & $(2.84,9.04,14.94)$ & $(0.83,3.08,8.15)$ \\
\hline & Fix. As. Turnover & T. Assets Turnover & Debt Ratio & Debt To Equity Ratio & Return On Assets \\
\hline AKENR & $(0.26,0.42,0.97)$ & $(0.22,0.34,0.71)$ & $(79.87,191.80,325.60)$ & $(44.33,62.27,76.47)$ & $(-9.57,0.00,10.36)$ \\
\hline AKSEN & $(0.47,0.74,1.02)$ & $(0.31,0.48,0.63)$ & $(163.1,232.7,303.2)$ & $(61.99,69.17,75.19)$ & $(-4.72,0.94,7.86)$ \\
\hline AKSUE & $(0.03,0.07,0.09)$ & $(0.02,0.06,0.08)$ & $(7.77,11.88,18.68)$ & $(7.21,10.53,15.74)$ & $(-5.88,1.83,10.03)$ \\
\hline ANELE & $(0.47,0.74,1.02)$ & $(0.49,0.57,0.69)$ & $(158.38,237.9,385.2)$ & $(61.99,69.17,75.19)$ & $(0.02,3.72,8.97)$ \\
\hline AVTUR & $(0.05,4.29,7.74)$ & $(0.02,66.45,136.7)$ & $(0.69,9.28,17.63)$ & $(0.69,8.30,14.99)$ & $(-3.96,-1.41,5.21)$ \\
\hline AYEN & $(0.17,0.27,0.38)$ & $(0.16,0.22,0.32)$ & $(93.45,203.45,421.13)$ & $(47.18,61.12,79.25)$ & $(-4.66,4.50,9.93)$ \\
\hline AYGAZ & $(2.15,2.49,2.83)$ & $(1.45,1.72,2.01)$ & $(24.19,42.09,70.80)$ & $(19.47,28.44,40.21)$ & $(1.70,8.91,13.94)$ \\
\hline EMKEL & $(0.75,1.32,2.88)$ & $(0.49,0.74,1.14)$ & $(-852.98,-9.22,245.53)$ & $(51.22,69.18,113.28)$ & $(-3.08,1.80,10.68)$ \\
\hline GEREL & $(1.53,2.96,5.55)$ & $(0.79,1.10,1.59)$ & $(53.40,125.51,193.50)$ & $(34.81,52.46,65.93)$ & $(-5.97,0.53,9.67)$ \\
\hline IPEKE & $(0.69,1.00,1.26)$ & $(0.42,0.52,0.63)$ & $(37.43,64.00,96.13)$ & $(10.67,19.48,30.39)$ & $(8.14,18.93,26.85)$ \\
\hline PETKM & $(1.63,2.43,3.20)$ & $(0.97,1.31,1.55)$ & $(25.19,55.42,90.08)$ & $(20.12,34.56,47.39)$ & $(-8.91,1.32,5.48)$ \\
\hline TRCAS & $(0.02,0.07,0.15)$ & $(0.01,0.06,0.11)$ & $(2.48,26.50,66.62)$ & $(2.42,17.82,39.98)$ & $(2.14,7.42,11.38)$ \\
\hline \multirow[t]{2}{*}{ ZOREN } & $(0.11,0.19,0.29)$ & $(0.10,0.16,0.26)$ & $(730.5,1645.7,3169.6)$ & $(87.87,94.10,103.85)$ & $(-13.86,-2.73,11.49)$ \\
\hline & Return On Equity & Net Profit Margin & Assets Growth & Shareh. Equity Growth & Sales Growth \\
\hline AKENR & $(-40.75,-4.78,18.66)$ & $(-38.1,-5.07,14.6)$ & $(13.38,33.84,74.36)$ & $(-31.65,19.35,79.82)$ & $(-23.61,12.19,43.22)$ \\
\hline AKSEN & $(-17.99,2.49,20.7)$ & $(-9.63,2.04,12.54)$ & $(-1.95,30.15,97.60)$ & $(-15.05,37.41,91.31)$ & $(-2.97,48.01,107.89)$ \\
\hline AKSUE & $(-6.34,2.08,11.32)$ & $(-74.4,32.5,134.4)$ & $(-7.35,7.00,26.26)$ & $(-5.41,5.23,23.29)$ & $(-45.1,28.08,241.9)$ \\
\hline ANELE & $(-16.21,16.90,77.7)$ & $(-9.63,2.04,12.54)$ & $(-7.26,42.79,117.39)$ & $(-15.05,37.41,91.31)$ & $(-2.97,48.01,107.8)$ \\
\hline AVTUR & $(-4.16,-1.41,6.13)$ & $(-147.7,-27.6,0.04)$ & $(-17.68,398.7,2393.8)$ & $(-3.8,372.03,2234.8)$ & $(-96.87,-31.27,46.56)$ \\
\hline AYEN & $(-24.77,8.18,20.3)$ & $(-14.76,22.4,43.4)$ & $(-5.78,20.81,84.46)$ & $(-15.50,0.73,9.42)$ & $(3.14,27.74,90.20)$ \\
\hline AYGAZ & $(2.99,12.27,19.05)$ & $(1.17,5.12,8.62)$ & $(-3.26,5.72,9.00)$ & $(2.21,2.45,2.68)$ & $(2.39,11.34,23.00)$ \\
\hline EMKEL & $(-6.30,9.25,36.91)$ & $(-6.25,1.15,10.19)$ & $(15.65,44.41,89.69)$ & $(-64.4,94.7,484.81)$ & $(-31.22,25.4,62.09)$ \\
\hline GEREL & $(-16.96,-1.80,14.83)$ & $(-5.92,-0.60,6.08)$ & $(-3.09,39.42,134.26)$ & $(-9.35,18.59,53.98)$ & $(-17.88,22.02,85.06)$ \\
\hline IPEKE & $(0.87,1.89,3.76)$ & $(18.47,36.08,47.5)$ & $(10.81,49.98,104.21)$ & $(6.86,47.87,106.10)$ & $(-7.90,35.82,67.66)$ \\
\hline PETKM & $(-11.15,2.44,8.13)$ & $(-6.52,1.28,5.54)$ & $(-12.72,9.55,24.43)$ & $(-11.44,2.09,8.85)$ & $(-11.33,12.95,41.41)$ \\
\hline TRCAS & $(3.57,9.01,15.56)$ & $(51.9,249,891.3)$ & $(-0.74,15.78,53.26)$ & $(-1.06,5.71,14.91)$ & $(-79.0,288.3,1593.2)$ \\
\hline ZOREN & $(-351.3,-104.9,99.3)$ & $(-106.2,-14.1,109)$ & $(-6.89,39.05,128.82)$ & $(-186.78,97.2,528.3)$ & $(-20.72,7.51,41.99)$ \\
\hline
\end{tabular}


After applying the steps, as a result of Fuzzy TOPSIS method, we rank the performance scores based on the financial ratios of 13 energy firms traded in Borsa Istanbul. As can be seen in Table 6, AVTUR, TRCAS and AKSUE which have the highest, AKENR and ZOREN have the lowest performance scores for the period 2008-2013.

Table 6. Performance Scores of the Energy Firms

\begin{tabular}{ccccc}
\hline Rank & Firm & $\mathbf{D}_{\mathbf{i}}{ }^{*}$ & $\mathbf{D}_{\mathbf{i}}{ }^{-}$ & $\mathbf{C C}_{\mathbf{i}}$ \\
\hline 1 & AVTUR & 0.987135044 & 0.904008183 & 0.478022061 \\
2 & TRCAS & 0.943099095 & 0.791095604 & 0.456174618 \\
3 & AKSUE & 0.982482711 & 0.807398341 & 0.451090501 \\
4 & IPEKE & 0.930515641 & 0.730387574 & 0.439753242 \\
5 & AYGAZ & 0.958963687 & 0.686787676 & 0.417309498 \\
6 & ANELE & 0.9968843 & 0.658097498 & 0.397646366 \\
7 & EMKEL & 1.009747287 & 0.648650772 & 0.391130928 \\
8 & GEREL & 1.011522564 & 0.642333239 & 0.388385274 \\
9 & PETKM & 1.009197933 & 0.640250196 & 0.388160249 \\
10 & AYEN & 1.017278487 & 0.63380406 & 0.383871819 \\
11 & AKSEN & 1.025402439 & 0.623030297 & 0.377953121 \\
12 & AKENR & 1.045277686 & 0.615486853 & 0.370604525 \\
13 & ZOREN & 1.277522836 & 0.516842079 & 0.288036216 \\
\hline
\end{tabular}

\section{Conclusion}

Energy has a critical impact on economic development level of countries due to being a driven force for the other sectors. Turkey's energy consumption has increased over the last years in parallel with industrialization and urbanization. Hence, energy sector has effect on other sectors of the economy, especially in the real economy. In this regard, financial performances of the firms must be followed-up due to the fact that any failure can affect all the economy.

The performance evaluation of the energy firms is an important issue especially in a competitive business environment for investors, creditors and also for the firms that are in the same sector since it settles firm's position in the sector. In addition, comparing a firm with others can identify the competitive strength and weakness of firm. In this respect, the results of the study provide useful information to the firms for reviewing their goals and strategies.

In the study, financial performances of Turkish energy firms are evaluated cover the period 20082013. Fuzzy AHP and Fuzzy TOPSIS methods are applied to the Turkish energy firms in order to evaluate the financial performances on the basis of 5 main criteria and 15 sub-criteria.

Firstly, the criteria used to measure the financial performance of the firms have been identified. Then, Fuzzy AHP method is utilized for the determination of the weights of the main and sub-criteria. The criteria of liquidity and profitability are the most significant with weight of 0.2963 , followed by the criteria of growth ratio (0.1467), financial leverage ratio (0.1314) and the activity ratio (0.1294) respectively. Then Fuzzy TOPSIS method is used for the ranking of thirteen firms in terms of financial performances. Results show that AVTUR, TRCAS and AKSUE have the best performance among the energy firms after the global financial crisis.

The results are important for the firms to realize the financial position in the energy sector. Moreover, by means of the results, firm managers could focus on the most effective criteria and imitate the proper firm. Although the study provides important insights of financial performances of the energy firms, it is possible to change the rankings of the firms if the weights of the criteria are changed by decision makers. A further research may consider the results obtained in this paper with other fuzzy multi-criteria 
decision making methods or the utilized method can be applied to the firms which are operate in other sectors.

\section{End Notes}

${ }^{1}$ where $S_{t}$ is the net sales of the current period, and $S_{t-1}$ is the net sales of the previous period.

${ }^{2}$ where $A_{t}$ is the assets of the current period, and $A_{t-1}$ is the assets of the previous period.

${ }^{3}$ where $E_{t}$ is the shareholders' equity of the current period and $E t_{-1}$ is shareholders' equity of the previous period.

${ }^{4}$ Fuzzy pairwise comparisons for the sub-criteria are presented in the appendix 2.

\section{References}

Akkoç, S., \& Vatansever, K. (2013). Fuzzy performance evaluation with AHP and TOPSIS methods: evidence for Turkish banking sector after the global financial crisis. Eurasian Journal of Business and Economics, 6, 53-74.

Beşkese, A., Demir, H. H., Özcan, H. K., \& Ökten, H. E. (2015). Landfill site selection using Fuzzy AHP and Fuzzy TOPSIS: A case study for Istanbul. Environment Earth Science, 73, 3513-3521.

Bronja, H., \& Bronja, H. (2014). Two-phase selection procedure of aluminized sheet supplier by applying Fuzzy AHP and Fuzzy TOPSIS methodology. Tecnicki Vjesnik, 22, 821-828.

Büyüközkan, G., Kahraman, C., \& Ruan, D. (2004). A fuzzy multi-criteria decision approach for software development strategy selection. International Journal of General Systems, 33, 259-280.

Chamodrakas, I. B. D., \& Martakos, D. (2010). Supplier selection in electronic marketplaces using satisficing and Fuzzy AHP. Expert Systems with Applications. 37, 490-498.

Chang, Y. H., Cheng, C.H., \& Wang, T.C. (2003). Performance evaluation of international airport in the region of East Asia. In Proceedings of Eastern Asia Society for transportation studies, 4, 213-230.

Chang, D. Y. (1996). Applications of the extent analysis method on Fuzzy AHP. European Journal of Operational Research. 95, 649-655.

Chen, F., Yizeng, C., Jian, Z., \& Yuanyuan, L. (2016). Optimizing h value for fuzzy linear regression with asymmetric triangular fuzzy coefficients. Engineering Applications of Artificial Intelligence, 47, 16-24.

Chen, G., \& Pham, T. T. (2001). Introduction to Fuzzy Sets, Fuzzy Logic and Fuzzy Control Systems, CRC Press, LLC.

Chen, J. F., Hsieh, H. N. \& Do, Q. H. (2015). Evaluating teaching performance based on Fuzzy AHP and comprehensive evaluation approach. Applied Soft Computing, 28, 100-108.

Chou, T. Y., \& Liang, G.S. (2001). Application of a fuzzy multi-criteria decision making model for shipping company performance evaluation. Maritime Policy \& Management, 28, 375-392.

Dymova, L., Sevastjanov, P., \& Tikhonenko, A. (2015). An interval type-2 fuzzy extension of the TOPSIS method using alpha cuts. Knowledge-Based Systems, 83, 116-127.

Erginel, N. \&Senturk, S. (2011). Ranking of the GSM operators with Fuzzy ANP. Proceedings of the World Congress on Engineering, June 6-8, London UK.

Ergül, N. (2010). IMKB'de işlem gören enerji şirketlerinin mali performanslarının TOPSis yöntemi ile analizi. Beta Yayınları, 1. Baskı.

Ertuğrul, E. \& Karakaşoğlu, N. (2009). Performance evaluation of Turkish cement firms with Fuzzy Analytic Hierarchy Process and TOPSIS methods. Expert System with Applications, 36, 702-715.

Feng, C. M., \& Wang, R.T. (2000). Performance evaluation for airlines including the consideration of financial ratios. Journal of Air Transport Management, 6, 133-142.

Gu, X., \& Zhu, Q. (2006). Fuzzy-multi attributes decision-making method based on eigenvector of fuzzy attribute evaluation space. Decision Support Systems, 41, 400-410.

Hu, J., \& Peng, J. (2008). Application of supplier selection based on the AHP theory, Knowledge Acquisition and Modeling Workshop (International Symposium), 1095-1097.

http://www.dogaka.gov.tr/Icerik/Dosya/www.dogaka.gov.tr_524_OP3D61SM_Enerji-Sektor-Raporu-2014.pdf, 10.01.2016.

Hwang, C. L., \& Yoon, K. (1981). Multiple attributes decision making methods and applications. Berlin: Springer. 
Ignatius, J., Behzadian, M., Malekan H. S., \& Lalitha, D. (2012). Financial performance of Iran's automotive sector based on PROMETHEE II. Proceeding of the IEEE ICMIT, 35-38.

Isaai, M. T., Kanani, A., Tootoonchi, M., \& Afzali, H. R. (2011). Intelligent timetable evaluation using Fuzzy AHP. Expert Systems with Applications, 38, 3718-3723.

Kalogeras, N., Baourakis, G., Zopounidis, C., \& Van Dijk, G. (2005). Evaluating the financial performance of agri-food firms: a multicriteria decision-aid approach. Journal of Food Engineering, 70, 365-371.

Kamvysi K., Gotzamani, K., Andronikidis, A. \& Georgiou, A. C. (2014). Capturing and prioritizing students' requirements for course design by embedding Fuzzy-AHP and linear programming in QFD. European Journal of Operational Research, 237, 1083-1094.

Kartalopolous, S. V. (1995). Understanding neural networks and fuzzy logic: basic concepts and applications, the institute of electrical and electronics engineers Inc., New York.

Kumar, A., Shankar, R., \& Debnath, R. M. (2015). Analyzing customer preference and measuring relative efficiency in telecom sector: a hybrid Fuzzy AHP/DEA study. Telematics and Informatics, 32, 447-462.

Kılınçcı, O. \& Önal, S. A. (2011). Fuzzy AHP approach for supplier selection in a washing machine company. Expert Systems with Applications, 38, 9656-9664.

Lee, C., Chiang, C., \& Chen, C. (2012). An evaluation model of e-service quality by applying hierarchical Fuzzy TOPSIS method. International Journal of Electronic Business Management, 10, 38-49.

Lee, S. K., Mogi, G., Lee, S. K., Hui, K. S., \& Kim, J. W. (2010). Econometric analysis of the R\&D performance in the national hydrogen energy technology development for measuring relative efficiency: the Fuzzy AHP/DEA integrated model approach. International Journal of Hydrogen Energy, 35, 2236-2246.

Lin, H. (2010). An application of Fuzzy AHP for evaluating course website quality. Computer \& Education, 54, 877-888.

Mahrooz, A., Maedeh, S., \& Morteza, P. (2013). Performance evaluation of banks using Fuzzy AHP and TOPSIS, case study: state-owned banks, particularly private and private banks in Iran. Caspain Journal of Applied Sciences Research, 2, 128-138.

Mandic, K., Delibasic, B., Knezevic, S., \& Benkovic, S. (2014). Analysis of the financial parameters of Serbian banks through the application of the Fuzzy AHP and TOPSIS methods. Economic Modelling, 43, 30-37.

Mangla, S. K., Kumar, P., \& Mukesh, K. B. (2015). Risk analysis in green supply chain using Fuzzy AHP approach: a case study, Resources, Conservations and Recycling, 104, 375-390.

Mosadeghi, R., Warnken, J., Tomlinson, R. \& Mirfenderesk, H. (2015). Comparison of Fuzzy-AHP and AHP in a spatial multi-criteria decision making model for urban land-use planning, computers. Environment and Urban Systems, 49, 54-65.

Nguyen, H. T., Md Dawal, S. Z., Nukman, Y., Aoyama, H. \& Case, K. (2015). An integrated approach for fuzzy linguistic preference based AHP and Fuzzy COPRAS for machine tool evaluation, Plos One, 1-24.

Punniyamoorty, M., Ponnusamy, M., \& Lakshmi, G. (2012). A combined application of Structural Equation Modeling (SEM) and Analytic Hierarchy Process (AHP) in supplier selection. Benchmarking: An International Journal, 19, 70-92.

Rezaei, J., Fahim, P. B. M., \& Tavasszy, L. (2014). Supplier selection in the airline retail industry using a funnel methodology: conjunctive screening method and Fuzzy AHP. Expert Systems with Applications, 41, 8165-8179.

Sakarya, Ş., Yıldırım, H.H., \& Akkuş, H.T. (2015). BiST'de işlem gören enerji şirketlerinin finansal performanslarının TOPSis çok kriterli karar verme yöntemi ile belirlenmesi, 19. Finans Sempozyumu, 21-24 Ekim, Çorum.

Seçme, N. Y., Bayrakdaroğlu, A., \& Kahraman, C. (2009). Fuzzy performance evaluation in Turkish banking sector using Analytic Hierarchy Process and TOPSIS. Expert Systems Applications, 36, 11699-11709.

Song, W., Ming, X., Wu, Z., \& Zhu, B. (2013). Failure modes and effects analysis using integrated weight-based Fuzzy TOPSIS. International Journal of Computer Integrated Manufacturing, 26, 1172-1186.

Sultana, I., Imtiaz, A., \& Azeem, A. (2015). An integrated approach for multiple criteria supplier selection combining Fuzzy Delphi, Fuzzy AHP \& Fuzzy TOPSIS. Journal of Intelligent \& Fuzzy Systems, 29, 1273-1287.

Sun, C. (2010). A performance evaluation model by integrating Fuzzy AHP and Fuzzy TOPSIS methods. Expert Systems with Applications, 37, 7745-7754.

Tanaka, K. (1997). An inroduction to fuzzy logic for practical applications, Springer-Verlag Newyork.

Viswanadham, N. \& Samvedi, A. (2013). Supplier selection based on supply chain ecosystem, performance and risk criteria. International Journal of Production Research, 51, 6484-6498. 
Wang, Y. J. (2008). Applying FMCDM to evaluate financial performance of domestic airlines in Taiwan. Expert Systems with Applications, 34, 1837-1845.

Weifeng, X., \& Gong, H. (2008). Using Fuzzy Analytic Hierarchy Process and Balanced Scorecard for commercial bank performance assessment. In Business and Information Management, IEEE, 1, 432-435.

Xia, W., \& Wu, Z. (2007). Supplier selection with multiple criteria in volume discount environments. Omega, 35, 494504.

Yalçın, N., Bayrakdaroğlu, A., \& Kahraman, C. (2012). Application of fuzzy multi-criteria decision making methods for financial performance evaluation of Turkish manufacturing industries. Expert Systems with Applications, 39, 350-364.

Yue, Z. (2013). An avoiding information loss approach to group decision making. Applied Mathematical Modeling, 37, 112-126.

Yurdakul, M., \& İç, Y. T. (2003). Türk otomotiv firmalarının performans ölçümü ve analizine yönelik TOPSIS yöntemini kullanan bir örnek çalışma. Gazi Üniversitesi Mühendislik Mimarlık Fakültesi Dergisi, 18, 1-18. 


\section{Appendix}

\section{Fuzzy Pairwise Comparisons for the Sub-Criteria}

\begin{tabular}{|c|c|c|c|c|}
\hline \multicolumn{5}{|l|}{ Liquidity Ratios } \\
\hline Current Ratio & $\begin{array}{c}\text { Current Ratio } \\
(1,1,1)\end{array}$ & $\begin{array}{c}\text { Quick Ratio } \\
(3,5,7)\end{array}$ & $\begin{array}{c}\text { Cash Ratio } \\
(1,1,3)\end{array}$ & \\
\hline Quick Ratio & $(0.143,0.2,0.333)$ & $(1,1,1)$ & $(0.2,0.333,1)$ & \\
\hline Cash Ratio & $(0.333,1,1)$ & $(1,3,5)$ & $(1,1,1)$ & \\
\hline \multicolumn{5}{|l|}{ Activity Ratios } \\
\hline & $\begin{array}{c}\text { Accounts Receivable } \\
\text { Turnover }\end{array}$ & $\begin{array}{l}\text { Fixed Assets } \\
\text { Turnover }\end{array}$ & $\begin{array}{l}\text { Equity } \\
\text { Turnover }\end{array}$ & $\begin{array}{l}\text { Total Assets } \\
\text { Turnover }\end{array}$ \\
\hline $\begin{array}{l}\text { Accounts Receivable } \\
\text { Turnover }\end{array}$ & $(1,1,1)$ & $(1,3,5)$ & $(3,5,7)$ & $(1,3,5)$ \\
\hline $\begin{array}{l}\text { Fixed Assets } \\
\text { Turnover }\end{array}$ & $(0.2,0.333,1)$ & $(1,1,1)$ & $(3,5,7)$ & $(1,3,5)$ \\
\hline $\begin{array}{l}\text { Equity } \\
\text { Turnover }\end{array}$ & $(0.143,0.2,0.333)$ & $(0.143,0.2,0.333)$ & $(1,1,1)$ & $(1,1,3)$ \\
\hline $\begin{array}{l}\text { Total Assets } \\
\text { Turnover }\end{array}$ & $(0.2,0.333,1)$ & $(0.2,0.333,1)$ & $(0.333,1,1)$ & $(1,1,1)$ \\
\hline \multicolumn{5}{|l|}{ Leverage Ratios } \\
\hline $\begin{array}{l}\text { Debt Ratio } \\
\text { Debt to Equity Ratio }\end{array}$ & $\begin{array}{c}\text { Debt Ratio } \\
(1,1,1) \\
(0.2,0.333,1)\end{array}$ & $\begin{array}{l}\text { Debt to Equity Ratio } \\
\qquad \begin{array}{c}(1,3,5) \\
(1,1,1)\end{array}\end{array}$ & & \\
\hline \multicolumn{5}{|l|}{ Profitability Ratios } \\
\hline $\begin{array}{l}\text { Return on Assets } \\
\text { Return on Equity } \\
\text { Net Profit Margin }\end{array}$ & $\begin{array}{c}\text { Return on Assets } \\
(1,1,1) \\
(0.2,0.333,1) \\
(0.2,0.333,1)\end{array}$ & $\begin{array}{c}\text { Return on Equity } \\
(1,3,5) \\
(1,1,1) \\
(0.333,1,1)\end{array}$ & $\begin{array}{c}\text { Net Profit Margin } \\
(1,3,5) \\
(1,1,3) \\
(1,1,1)\end{array}$ & \\
\hline \multicolumn{5}{|l|}{ Growth Ratios } \\
\hline $\begin{array}{l}\text { Sales Growth } \\
\text { Assets Growth } \\
\text { Shareholders' Equity } \\
\text { Growth }\end{array}$ & $\begin{array}{c}\text { Sales Growth } \\
(1,1,1) \\
(0.2,0.333,1) \\
(0.143,0.2,0.333)\end{array}$ & $\begin{array}{l}\text { Assets Growth } \\
\qquad \begin{array}{c}(1,3,5) \\
(1,1,1) \\
(0.2,0.333,1)\end{array}\end{array}$ & $\begin{array}{c}\text { Shareholders' Equity } \\
\text { Growth } \\
(3,5,7) \\
(1,3,5) \\
(1,1,1)\end{array}$ & \\
\hline
\end{tabular}




\section{Questionnaire Forms}

\begin{tabular}{|c|c|c|c|c|c|c|c|c|c|c|}
\hline Main Criteria & $\begin{array}{l}\frac{y}{J} \\
\frac{J}{0} \\
\frac{0}{4}\end{array}$ & 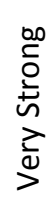 & 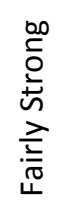 & $\frac{\text { 离 }}{\sum_{3}^{\frac{d}{3}}}$ & $\begin{array}{l}\overline{\frac{\pi}{\sigma}} \\
\overline{\tilde{U}}\end{array}$ & 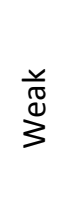 & 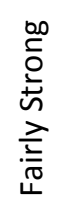 & 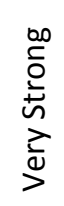 & $\begin{array}{l}\frac{y}{3} \\
\frac{\partial}{0} \\
\frac{0}{2}\end{array}$ & \\
\hline Growth Ratios & & & & & & & & & & Activity Ratios \\
\hline Growth Ratios & & & & & & & & & & Financial Leverage Ratios \\
\hline Growth Ratios & & & & & & & & & & Profitability Ratios \\
\hline Growth Ratios & & & & & & & & & & Liquidity Ratios \\
\hline Activity Ratios & & & & & & & & & & Financial Leverage Ratios \\
\hline Activity Ratios & & & & & & & & & & Profitability Ratios \\
\hline Activity Ratios & & & & & & & & & & Liquidity Ratios \\
\hline Financial Leverage Ratios & & & & & & & & & & Profitability Ratios \\
\hline Financial Leverage Ratios & & & & & & & & & & Liquidity Ratios \\
\hline Profitability Ratios & & & & & & & & & & Liquidity Ratios \\
\hline
\end{tabular}

\begin{tabular}{|c|c|c|c|c|c|c|c|c|c|c|}
\hline Liquidity Ratios & 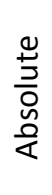 & 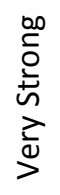 & 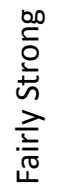 & 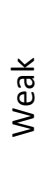 & $\begin{array}{l}\overline{\frac{\pi}{3}} \\
\overline{\frac{5}{6}}\end{array}$ & 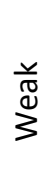 & 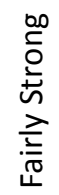 & 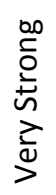 & $\begin{array}{l}\frac{y}{3} \\
\frac{0}{0} \\
\frac{0}{<}\end{array}$ & \\
\hline Current Ratio & & & & & & & & & & Quick Ratio \\
\hline Current Ratio & & & & & & & & & & Cash Ratio \\
\hline Quick Ratio & & & & & & & & & & Cash Ratio \\
\hline
\end{tabular}

\begin{tabular}{|c|c|c|c|c|c|c|c|c|c|c|}
\hline Activity Ratios & 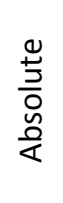 & 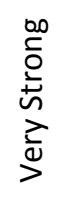 & 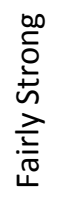 & $\stackrel{\frac{\text { IJ }}{\stackrel{d}{3}}}{3}$ & $\begin{array}{l}\overline{\frac{\pi}{0}} \\
\frac{\overrightarrow{2}}{\mathrm{U}}\end{array}$ & 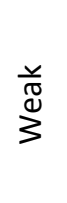 & 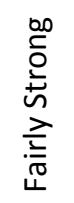 & 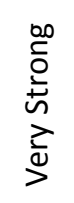 & 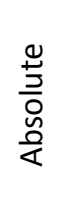 & \\
\hline $\begin{array}{c}\text { Accounts Receivable } \\
\text { Turnover }\end{array}$ & & & & & & & & & & Equity Turnover \\
\hline $\begin{array}{c}\text { Accounts Receivable } \\
\text { Turnover }\end{array}$ & & & & & & & & & & Fixed Assets Turnover \\
\hline $\begin{array}{c}\text { Accounts Receivable } \\
\text { Turnover }\end{array}$ & & & & & & & & & & Total Assets Turnover \\
\hline Equity Turnover & & & & & & & & & & Fixed Assets Turnover \\
\hline Equity Turnover & & & & & & & & & & Total Assets Turnover \\
\hline Fixed Assets Turnover & & & & & & & & & & Total Assets Turnover \\
\hline
\end{tabular}


K. Eyuboglu - P. Celik

\begin{tabular}{|c|c|c|c|c|c|c|c|c|c|c|}
\hline Financial Leverage Ratios & $\begin{array}{l}\frac{ \pm}{J} \\
\frac{\partial}{0} \\
\frac{0}{<}\end{array}$ & 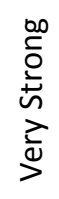 & 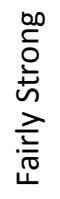 & 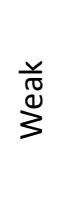 & $\begin{array}{l}\overline{\frac{\pi}{3}} \\
\overline{\mathrm{U}}\end{array}$ & $\begin{array}{l}\frac{\text { बू }}{3} \\
3\end{array}$ & 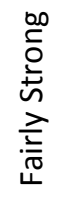 & 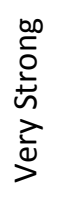 & $\begin{array}{l}\frac{y}{3} \\
\frac{\partial}{0} \\
\frac{a}{2}\end{array}$ & \\
\hline Debt Ratio & & & & & & & & & & Debt to Equity Ratio \\
\hline
\end{tabular}

\begin{tabular}{|c|c|c|c|c|c|c|c|c|c|c|}
\hline Profitability Ratios & 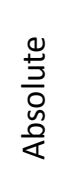 & 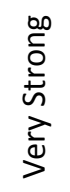 & 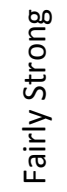 & 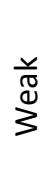 & $\begin{array}{l}\overline{\frac{\pi}{3}} \\
\overline{\tilde{J}}\end{array}$ & 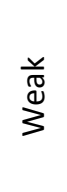 & 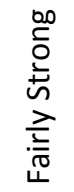 & 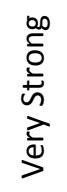 & $\begin{array}{l}\frac{ \pm}{3} \\
\frac{0}{0} \\
\frac{0}{<}\end{array}$ & \\
\hline Return on Equity & & & & & & & & & & Return on Assets \\
\hline Return on Equity & & & & & & & & & & Net Profit Margin \\
\hline Return on Assets & & & & & & & & & & Net Profit Margin \\
\hline
\end{tabular}

\begin{tabular}{|c|c|c|c|c|c|c|c|c|c|c|}
\hline Growth Ratios & $\begin{array}{l}\frac{D}{J} \\
\frac{0}{0} \\
\frac{0}{<}\end{array}$ & 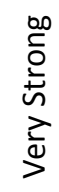 & 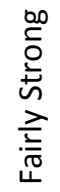 & $\frac{\substack{\text { \% } \\
3}}{3}$ & 嵒 & $\sum_{3}^{\frac{\pi}{\pi}}$ & 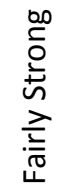 & 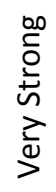 & $\begin{array}{l}\frac{y}{3} \\
\frac{\partial}{0} \\
\stackrel{0}{\alpha}\end{array}$ & \\
\hline Assets Growth & & & & & & & & & & $\begin{array}{c}\text { Shareholders' Equity } \\
\text { Growth }\end{array}$ \\
\hline Assets Growth & & & & & & & & & & Sales Growth \\
\hline Shareholders' Equity Growth & & & & & & & & & & Sales Growth \\
\hline
\end{tabular}


This Page Intentionally Left Blank 